\title{
Biological Control of Grape Crown Gall by Rahnella aquatilis HX2
}

\author{
F. Chen, Y. B. Guo, J. H. Wang, J. Y. Li, and H. M. Wang, Department of Plant Pathology, China Agricultural \\ University, Beijing 100094, PR. China
}

\begin{abstract}
Chen, F., Guo, Y. B., Wang, J. H., Li, J. Y., and Wang, H. M. 2007. Biological control of grape crown gall by Rahnella aquatilis HX2. Plant Dis. 91:957-963.

Crown gall induced by Agrobacterium vitis is a worldwide plant disease in grape-growing regions. Rahnella aquatilis HX2, a new isolate from vineyard soil in Beijing, showed a significant inhibition effect on the development of crown galls in grapevines. In field trials, immersion of the basal ends of grape cuttings with HX2 cell suspension inhibited or completely prevented crown gall formation caused by A. vitis $\mathrm{K} 308$ in the roots of the plants from the cuttings. The 3year average disease incidence in grape plants treated with HX2 was $30.8 \%$ compared to $93.5 \%$ in plants without HX2. The culture supernatant of HX2 exhibited a stronger inhibition effect on disease development than did the cell suspension. HX2 could be found in the grape rhizosphere, grown under field conditions, for up to 90 days after inoculation. There was no significant difference in the mean population sizes of root microflora between plants treated and not treated with HX2. The inhibition effect of HX2 on crown gall in sunflower, caused by different agrobacterial strains, varied between 30.7 and $100 \%$, depending on strains. Our results showed that Rahnella aquatilis HX2 may be used as a biological control agent for crown gall disease of grapes.
\end{abstract}

Following apple, citrus, pear, and banana, grape production now ranks fifth in fruit production in China. According to data published by the China Ministry of Agriculture, in 2004, the area under cultivation to grapes was estimated to be 413,500 hectares and their production to be $5,675,000$ tons. Crown gall disease is one of the most destructive diseases of grapevine in China. It seriously affects the quantity and quality of grape production. In some vineyards, the incidence of crown gall disease is as high as 30 to $70 \%$ (51). To date, no effective chemical treatments are available for grape crown gall control.

The causal organism of crown gall disease is Agrobacterium vitis (31). Tumors form on roots and trunks as well as on branches. Biological control of crown gall disease has been implemented since Agrobacterium rhizogenes $\mathrm{K} 84$ was used commercially to control peach crown gall in 1980 (22). However, K84 is only effective in controlling crown gall caused by nopaline-type strains of $A$. tumefaciens and A. rhizogenes, and has no effect on crown galls induced by $A$. vitis in grapevines $(6,22,23,42)$.

Many avirulent strains of Agrobacterium have been reported as biological control agents of the pathogens resistant to $\mathrm{K} 84$,

Corresponding author: H. M. Wang
E-mail: wanghm69@cau.edu.cn

Accepted for publication 15 January 2007

doi:10.1094/PDIS-91-8-0957

(C) 2007 The American Phytopathological Society whose active compound is agrocin 84 $(7,10,48)$. In addition to those Agrobacterium antagonistic strains, Bacillus subtilis AB8 and several Pseudomonas strains were found to be potential biocontrol agents to reduce the incidence of crown gall $(24,44,52)$. Bell et al. demonstrated that certain grapevine endophytes can control population numbers of Agrobacterium in situ and provide significant biocontrol of crown gall (2).

This paper reports on Rahnella aquatilis HX2 and its antagonistic activity on crown gall of sunflower and grape.

\section{MATERIALS AND METHODS}

Bacterial strains and the plasmid used in this study. Bacterial strains and the plasmid used in this study and their relevant characteristics are presented in Table 1. Strain HX2, isolated from vineyard soil in the course of a screening program for antagonistic rhizospheric bacteria, was naturally resistant to ampicillin (Amp, 200 $\mu \mathrm{g} / \mathrm{ml})$. This antagonistic bacterium has not been previously isolated in China.

Culture and growth media. HX2 was grown on $1.5 \%$ (vol/wt) potato dextrose agar (PDA) medium (100 g potato, $10 \mathrm{~g}$ dextrose, and $15 \mathrm{~g}$ agar per liter) at $28^{\circ} \mathrm{C}$. Escherichia coli DH5 $\alpha$ was cultured at $37^{\circ} \mathrm{C}$ in Luria-Bertani broth (LB) $(10 \mathrm{~g}$ tryptone, $5 \mathrm{~g}$ yeast extract, and $10 \mathrm{~g} \mathrm{NaCl}$ per liter) or on LB agar plates. The agrobacterial strains and soil bacteria were

Table 1. Bacterial strains and the plasmid used in this study

\begin{tabular}{lll}
\hline Strain or plasmid & Relevant characteristics & Source \\
\hline HX2 & Amp $^{\mathrm{r}}$ & This study \\
Escherichia coli DH5 $\alpha$ & & Provence (36) \\
Agrobacterium tumefaciens & & \\
C58 & Nop & LaPointe (27) \\
AC11 & Nop & Kerr (23) \\
B6S3 & Oct & Whatley (50) \\
MG14-2 & Nop & This study \\
MG10-1 & Nop & This study \\
CY4 & Nop & This study \\
CY31 & Nop & This study \\
CY32 & Nop & This study \\
Pt12 & Agr & This study \\
Y5-1 & Nop & This study \\
MI4-6 & Oct & This study \\
Agrobacterium rhizogenes & & \\
K27 & Nop & Kerr (23) \\
K75 & Nop & This study \\
NL12-2 & Nop & This study \\
HBT3-4 & Nop & This study \\
B1 & Nop & This study \\
D2 & Nop & This study \\
Agrobacterium vitis & & \\
K308 & Oct & Kerr (22) \\
G11(3) & Oct & This study \\
G7(2) & Oct & This study \\
MI23-1 & Oct & This study \\
MB26-1 & Oct & This study \\
MB26-1 & Oct & This study \\
Plasmid & & \\
pSMC2 & Km & Bloemberg (4) \\
\hline
\end{tabular}

a $\mathrm{Amp}^{\mathrm{r}}, \mathrm{Km}^{\mathrm{r}}$, designate resistance to ampicillin and kanamycin, respectively; Nop, nopaline type; Oct, octopine type; Agr, agropine type; $\mathrm{GFP}^{+}$, green fluorescent protein positive. 
grown at $28^{\circ} \mathrm{C}$ on $1.5 \%$ (vol/wt) modified 523 agar (10 g sucrose, $2 \mathrm{~g} \mathrm{KH}_{2} \mathrm{PO}_{4}, 10 \mathrm{~g}$ yeast extract, $5 \mathrm{~g} \mathrm{CaCO}_{3}, 0.2 \mathrm{~g} \mathrm{NaCl}_{\text {, and }}$ $0.3 \mathrm{~g} \mathrm{MgSO}_{4} \cdot 7 \mathrm{H}_{2} \mathrm{O}$ per liter). Soil fungal strains were cultured at $26^{\circ} \mathrm{C}$ on $1.5 \%$ (vol/wt) Martin broth (10 $\mathrm{g}$ dextrose, $5 \mathrm{~g}$ peptone, $1.0 \mathrm{~g} \quad \mathrm{KH}_{2} \mathrm{PO}_{4}, 0.5 \mathrm{~g}$ $\mathrm{MgSO}_{4} \cdot 7 \mathrm{H}_{2} \mathrm{O}$, and $0.03 \mathrm{~g}$ Bengal red per liter, and streptomycin sulfate at $30 \mu \mathrm{g} / \mathrm{ml}$ ), and the actinomyces grew at $30^{\circ} \mathrm{C}$ on $1.5 \%$ (vol/wt) Gause's no. 1 synthetic medium (20 g starch soluble, $1 \mathrm{~g} \mathrm{KNO}_{3}, 0.5 \mathrm{~g}$ $\mathrm{K}_{2} \mathrm{HPO}_{4}, 0.5 \mathrm{~g} \mathrm{MgSO}_{4} \cdot 7 \mathrm{H}_{2} \mathrm{O}, 0.5 \mathrm{~g} \mathrm{NaCl}$, $0.01 \mathrm{~g} \mathrm{FeSO}_{4}$, and $0.1 \mathrm{~g} \mathrm{~K}_{2} \mathrm{Cr}_{2} \mathrm{O}_{7}$ per liter) (15).

Chrome Azurol S (CAS) agar medium was prepared according to Schwyn and Neilands (39). HX2 was inoculated onto the center of CAS medium plates and incubated at $28^{\circ} \mathrm{C}$ for 3 days. A yellow halo surrounding the colony indicated a positive reaction.

$\mathrm{HCN}$ production was assayed according to the method described by Castric and Castric (9) with the following modifications: a single colony of strain $\mathrm{HX} 2$ that is $18 \mathrm{~h}$ old was inoculated into the Eppendorf tube containing $0.5 \mathrm{ml}$ of solid LB medium. A small piece of $\mathrm{HCN}$-sensitive detection paper was hung over the medium. The tube was sealed with Parafilm and then incubated at $28^{\circ} \mathrm{C}$ for $48 \mathrm{~h}$. The $\mathrm{HCN}$-sensitive paper was Whatman chromatography paper soaked in the $\mathrm{HCN}$ detection reagent: copper (II) ethyl acetoacetate $(5 \mathrm{mg})$ and 4,4'-methylenebis$(N, N$-dimethylaniline) $(5 \mathrm{mg})$ in chloroform (1 to $2 \mathrm{ml}$ ). A blue color indicates the production of HCN of strain HX2.

Growth of sunflower seedlings and grapevine. Sunflower (Helianthus annuus L. cv. Frankasol) and grapevine (Vitis vinifera L. cv. Muscat Hamburg) were obtained from the Ministry of Agriculture, China. Sunflower seedlings were grown in pots (7 $\mathrm{cm}$ diameter) containing a mixture of sterile clay soil and vermiculite (1:1) and watered as required. Grapevine plants were grown in pots ( $26 \mathrm{~cm}$ diameter) containing the same soil mixture. All plants were kept at room temperature with a 16-h photoperiod.

Identification of strain HX2. The ability to utilize different carbon sources was tested using the Biolog identification system (Biolog Inc., Hayward, CA). The morphological, cultural, biochemical, and physiological characteristics of HX2 were examined according to the methods previously reported by Iimura and Hosono (20). Briefly, catalase production was detected by the production of bubbles in a $3 \%$ hydrogen peroxide solution. The oxidase test was carried out by use of cytochrome oxidase test paper. Phenylalanine agar and ferric chloride solution were used to detect the production of phenylpyruvic acid.

HX2 genomic DNA was extracted and purified according to the method described by Ausubel et al. (1). Briefly, $30 \mu \mathrm{l}$ of so- dium dodecyl sulfate (SDS) (10\%) and 3 $\mu \mathrm{l}$ of Proteinase K $(30 \mu \mathrm{g} / \mathrm{ml})$ were added to $567 \mu \mathrm{l}$ of bacterial cells suspended in TE buffer, and the mixture was incubated at $37^{\circ} \mathrm{C}$ for $1 \mathrm{~h}$, followed by the addition of $100 \mu \mathrm{l}$ of $\mathrm{NaCl}(5 \mathrm{M})$ and $50 \mu \mathrm{l}$ of $\mathrm{CTAB} / \mathrm{NaCl}$. The mixture was incubated at $65^{\circ} \mathrm{C}$ for $10 \mathrm{~min}$ and extracted with phenol/chloroform/isoamyl alcohol (25:24:1 $\mathrm{vol} / \mathrm{vol} / \mathrm{vol})$. The DNA was precipitated by adding 0.6 volume of isopropanol, separated by centrifugation $(10,000 \times g)$, washed with $70 \%$ ethanol, and dried. The $16 \mathrm{~S}$ rDNA was polymerase chain reaction (PCR) amplified from HX2 genomic DNA with the primers 63F 5'-CAGGCC TAACACATGCAAGTC-3' and 1494R 5'GGYTACCTTGTTACGACTT-3' and then sequenced.

Inhibition test in vitro. Antagonist activity of the HX2 against pathogenic agrobacterial strains was studied according to Stonier's method (40) with the following modifications: a drop of $10 \mu \mathrm{HX} 2$ cell suspension was added on the center of PDA medium plates and incubated at $28^{\circ} \mathrm{C}$ for $48 \mathrm{~h}$. Then the cells were killed with chloroform. After evaporation of the chloroform, 50- $\mu$ l aliquots of agrobacterial strains (ca. $2 \times 10^{8} \mathrm{CFU} / \mathrm{ml}$ ) mixed with 5 $\mathrm{ml}$ of $0.7 \%$ yeast extract broth (YEB) (46) soft agar was poured over the surfaces of the inoculated PDA plates. The plates were incubated at $28^{\circ} \mathrm{C}$ for $24 \mathrm{~h}$, the inhibition zones around the killed HX2 colonies were observed, and the diameters were measured. Each strain was tested on five replicate plates at least twice.

Inhibition test in vivo. Sunflower seedlings with two true leaves grown in a greenhouse were used for in vivo tests. HX2 was cultured in liquid PDA medium and grown on a shaker at $180 \mathrm{rpm}$ at $28^{\circ} \mathrm{C}$ for $28 \mathrm{~h}$. Cells were pelleted and washed twice with sterile distilled water and then suspended in sterile buffered saline to get an $\mathrm{OD}_{600}$ of 0.6 (ca. $2 \times 10^{8} \mathrm{CFU} / \mathrm{ml}$ ). The supernatant was retained. The suspension of the agrobacterial strain $\left(2 \times 10^{8}\right.$ $\mathrm{CFU} / \mathrm{ml}$ ) was mixed with two volumes of (i) the supernatant, (ii) sterile buffered saline $(0.85 \% \mathrm{NaCl})$, or (iii) the cell suspension of HX2.

Sunflower stems were wounded by making a $0.5-\mathrm{cm}$ longitudinal cut with a sterile needle. A drop of the mixture $(3 \mu \mathrm{l})$ was placed on the wounding site. Each of 30 plants per treatment was inoculated at one site that was immediately wrapped with Parafilm. Gall formation was observed, and the gall was excised and weighed 15 days after inoculation. The crown gall tumor inhibition activity was calculated as follows: Crown gall tumor inhibition $(\%)=$ $[(C-T) / C] \times 100$, where $C$ is the average weight of the crown gall tumor of the control group, and $T$ is the average weight of the crown gall tumor of the treated group.

The suspension of A. vitis K308 obtained as described above was mixed with two volumes of (i) sterile buffered saline, (ii) cell suspension, or (iii) supernatant of HX2. Four intact grapevines were used in the experiments, and each plant contained four inoculation sites. The current-year stem of grapevine was wounded by making a $0.8-\mathrm{cm}$ longitudinal cut with a sterile sharp scalpel, and a $10-\mu l$ drop was placed into each wound site. The inoculation site was wrapped with Parafilm. Gall formation was observed and tumor weight was measured 30 days after inoculation. The biological activity of the HX2 against gall agrobacterium K308 was evaluated based on the tumor weight as described above.

Field test. The ability of HX2 to inhibit gall formation caused by $A$. vitis K308 was also assessed under field conditions in Changli, Hebei province, China. One-yearold cuttings of Muscat Hamburg grapevine, free of crown galls and with two to three nodes each, were used in the field experiment. Prior to planting, the basal ends of the cuttings were soaked in a mixture of the HX2 and K308 cultures (1:1) for $10 \mathrm{~min}$. Other cuttings were soaked only in K308 culture as a control treatment. Each treatment consisted of four rows and each row was applied to 20 plants. The rows were blocks and the experimental design was a randomized complete block. Crown gall formation was assessed and the weight of the tumor was measured 8 months after planting. Tumor inhibition activity was calculated as above. The experiment was conducted for three consecutive years.

Root colonization on grapevine. Preparation of HX2 competent cells and the plasmid pSMC2, which contained green fluorescent protein (GFP) gene, and electroporation were performed according to the protocols of Sambrook et al. (38): HX2 cells (ca. $2 \times 10^{10}$ cells) were washed three times with ice-cold double-distilled water $\left(\mathrm{ddH}_{2} \mathrm{O}\right)$ and then resuspended in a small volume $(40 \mu \mathrm{l})$ of ice-cold 10 glycerol; $0.2 \mu \mathrm{g}$ of plasmid DNA was mixed with $40 \mu \mathrm{l}$ of these cells, added to a 2-mmgap electroporation cuvette, and electroporated at $2.0 \mathrm{kV}$ with a Gene Pulser (BioRad, Melville, NY). The electroporated cells were diluted into $1 \mathrm{ml}$ of PDA medium and grown for $1 \mathrm{~h}$ before being plated on modified 523 agar supplemented with Amp $(200 \mu \mathrm{g} / \mathrm{ml})$ and kanamycin $(50$ $\mu \mathrm{g} / \mathrm{ml})$. Stability of pSMC2 in the strain HX2 was analyzed by the method described by Van der Bij et al. (45): a single colony of strain HX2 harboring the plasmid pSMC2 was inoculated into PDA medium supplemented with Amp (200 $\mu \mathrm{g} / \mathrm{ml})$ and kanamycin $(50 \mu \mathrm{g} / \mathrm{ml})$. After 18 $\mathrm{h}$ of growth, bacterial suspension was centrifuged and washed twice with sterile water to remove the antibiotics. PDA medium was inoculated with approximately $10^{8} \mathrm{CFU}$ of $\mathrm{HX} 2$ per $\mathrm{ml}$, and the culture was allowed to grow for $12 \mathrm{~h}$ at $28^{\circ} \mathrm{C}$ on a rotary shaker. Suspension was diluted 
1,000-fold in 10-ml aliquots of fresh nonselective PDA medium. This procedure was repeated at least 40 generations without antibiotic pressure after the initial inoculation. During the course of the experiment, the sample was taken, diluted, and plated on modified 523 agar without or supplemented by Amp $(200 \mu \mathrm{g} / \mathrm{ml})$ and kanamycin $(50 \mu \mathrm{g} / \mathrm{ml})$. The stability of plasmid pSMC2 was determined by comparing the numbers of colonies present on selective and nonselective plates.

The modified HX2 strain harboring plasmid pSMC2 was used to analyze survival of HX2 in the grapevine roots as described by Vicedo et al. (47). Thirty-oneyear-old grape plants were inoculated with $\mathrm{HX} 2$ by immersing the roots for $10 \mathrm{~min}$ in the cell suspension $\left(1 \times 10^{8} \mathrm{CFU} / \mathrm{ml}\right)$. An additional 30 plants were treated with sterile water as controls. In order to detect the dynamic of population of HX2 in the grape root under natural conditions, inoculated plants were planted in nonsterile field soil. After various periods following planting (1, 15, 30, 60, 90, and 120 days), three plants of each treatment were uprooted and adhering soil was removed. The roots were placed in $100 \mathrm{ml}$ of $0.25 \times$ Ringer's Solution (1× Ringer's Solution containing 2.25 $\mathrm{g} \mathrm{NaCl}, 0.105 \mathrm{~g} \mathrm{KCl}, 0.06 \mathrm{~g} \mathrm{CaCl}_{2}$, and $0.05 \mathrm{~g} \mathrm{NaHCO}_{3}$ per liter) and shaken for $10 \mathrm{~min}$ at $180 \mathrm{rpm}$. A series of dilutions of the root solutions were plated on the media of modified 523 agar containing Amp (200 $\mu \mathrm{g} / \mathrm{ml})$ and kanamycin $(50 \mu \mathrm{g} / \mathrm{ml})$. After incubation for $48 \mathrm{~h}$ at $28^{\circ} \mathrm{C}$, fluorescent green pigment colonies were counted and

Table 2. Reaction of Rahnella aquatilis HX2 in routine biochemical tests

\begin{tabular}{lc}
\hline Biochemical reaction & Result \\
\hline Growth on $2 \% \mathrm{NaCl}$ & + \\
Catalase & + \\
Citrate utilization & + \\
Methyl red & - \\
Voges-Proskauer & + \\
Growth at $4^{\circ} \mathrm{C}$ or $41^{\circ} \mathrm{C}$ & + \\
Phenylalanine deaminase & - \\
Arginine dihydrolase & + \\
Lysine decarboxylase & - \\
Ornithine decarboxylase & - \\
Motility & + \\
Gelatin liquefaction $\left(20^{\circ} \mathrm{C}\right)$ & - \\
Cytochrome oxidase & - \\
Cellulose decomposition & - \\
Amylase & - \\
$\mathrm{H}_{2}$ S production & - \\
Malonate & + \\
Gas from D-glucose & + \\
Utilization of tartrate & - \\
Utilization of D-acetate & - \\
Utilization of L-phenylalanine & + \\
Utilization of Urethane & - \\
Acid from: & + \\
D-Arabitol & + \\
D-Mannose & + \\
D-Sorbitol & + \\
Sucrose & + \\
D-glucose & + \\
Ethanol & \\
Inositol & + \\
\hline
\end{tabular}

the numbers of CFU per gram of roots were calculated. For the purpose of confirmation, five randomly selected $\mathrm{HX} 2$ colonies were tested for antagonistic activity against $A$. vitis K308. The $16 \mathrm{~S}$ rDNA were amplified from the five colonies and sequenced.

The population of rhizosphere microflora of grapevine was also analyzed at the same time. The rhizosphere soil dilutions were plated on the modified 523 agar, Martin broth, and Gause's no. 1 synthetic medium for obtaining bacteria, fungi, and actinomyces, respectively.

Statistical analysis. An analysis of variance was performed on the data with SAS (version 8.2; SAS Institute, Inc., Cary, NC). The mean square error values were tested with a $t$ test at $P<0.05$.

\section{RESULTS}

Isolate characterization. The antagonistic strain HX2 was identified by the Biolog identification system as Rahnella aquatilis. The strain HX2 was small, rodshaped, gram negative, and the biochemical test results showed that it was negative for cytochrome oxidase and positive for catalase (Table 2). It was typically a member of the Enterobacteriaceae family.

Siderophores were not produced on the CAS agar and it was HCN negative.

The 16S rDNA sequence was 99\% identical to that of the genus Rahnella.
Inhibition of agrobacterial strains in vitro. Strain HX2 exhibited inhibitory activity against 11 isolates of $A$. tumefaciens, 5 isolates of $A$. rhizogenes, and 5 isolates of A. vitis (Table 3.). The inhibitory effect of $\mathrm{HX} 2$ on the growth of $A$. vitis K308 was clearly demonstrated in Figure 1.

In vivo tests. Application of strain $\mathrm{HX} 2$ in sunflower plants resulted in reduced infection by agrobacterial strains (Table 3 , Fig. 2). When the culture supernatant and cell suspension of the HX2 were applied, the crown gall symptoms caused by phytopathogenic agrobacteria decreased by $39.8 \% \sim 100 \%$ and $30.7 \% \sim 92.9 \%$, respectively, depending on pathogenic strains. The inhibitory efficacy of the supernatant was generally higher than that of the cell suspension except for controlling A. tumefaciens PT12.

Application of strain HX2 in grapevines resulted in reduced infection by $A$. vitis K308. Both HX2 cell suspension and the supernatant reduced crown gall symptoms as shown in Figure 3. The inhibition effects of supernatant and cell suspension were 100 and $63 \%$, respectively.

Field experiment. In the first year, incidence of crown gall on plants treated and nontreated with $\mathrm{HX} 2$ were 31.3 and $93.8 \%$, respectively, and the crown gall tumor inhibition was $81.8 \%$. In the second year, incidence of crown gall on plants

Table 3. Antagonistic effect of Rahnella aquatilis HX2 to agrobacterial strains on potato dextrose agar (PDA) plates and inhibition effect of the supernatant and cell suspension of HX2 on tumor formation by agrobacterial strains in sunflower

\begin{tabular}{|c|c|c|c|}
\hline \multirow[b]{2}{*}{ Strain } & \multirow{2}{*}{$\begin{array}{l}\text { Inhibition zone (dia.) } \\
\text { (mm) }\end{array}$} & \multicolumn{2}{|c|}{ Efficiency of biocontrol $(\%)^{a}$} \\
\hline & & Supernatant & Cells \\
\hline \multicolumn{4}{|c|}{ Agrobacterium tumefaciens } \\
\hline C58 & $28.8 \pm 3.5^{\mathrm{b}}$ & $82.6 \pm 7.5$ & $60.9 \pm 11.2$ \\
\hline AC11 & $29.7 \pm 3.6$ & $80.6 \pm 4.8$ & $61.1 \pm 9.6$ \\
\hline B6S3 & $35.9 \pm 2.1$ & $39.8 \pm 9.7$ & $30.7 \pm 0$ \\
\hline MG14-2 & $27.7 \pm 2.1$ & $96.1 \pm 3.3$ & $84.6 \pm 8.8$ \\
\hline MG10-1 & $42.9 \pm 5.2$ & $66.7 \pm 2.5$ & $63.8 \pm 2.5$ \\
\hline CY4 & $30.0 \pm 3.8$ & $100 \pm 0$ & $92.9 \pm 7.1$ \\
\hline CY31 & $24.3 \pm 1.9$ & $100 \pm 0$ & $89.7 \pm 2.5$ \\
\hline CY32 & $28.5 \pm 2.6$ & $80.0 \pm 6.9$ & $78.0 \pm 9.2$ \\
\hline Pt12 & $30.5 \pm 3.7$ & $80.0 \pm 8.8$ & $86.5 \pm 2.9$ \\
\hline Y5-1 & $39.8 \pm 2.1$ & $92.1 \pm 5.5$ & $82.6 \pm 2.7$ \\
\hline MI4-6 & $38.0 \pm 2.8$ & $100 \pm 0$ & $66.7 \pm 4.4$ \\
\hline \multicolumn{4}{|c|}{ A. rhizogenes } \\
\hline $\mathrm{K} 27$ & $26.4 \pm 1.9$ & $64.6 \pm 8.8$ & $63.3 \pm 7.9$ \\
\hline K75 & $39.1 \pm 3.4$ & $64.6 \pm 8.8$ & $62.1 \pm 3.8$ \\
\hline NL12-2 & $41.3 \pm 2.5$ & $97.1 \pm 4.8$ & $84.6 \pm 4.8$ \\
\hline B1 & $40.8 \pm 2.7$ & $96.1 \pm 3.9$ & $83.1 \pm 4.5$ \\
\hline D2 & $30.8 \pm 3.7$ & $100 \pm 0$ & $81.5 \pm 6.4$ \\
\hline \multicolumn{4}{|l|}{ A. vitis } \\
\hline K308 & $33.8 \pm 3.3$ & $93.9 \pm 6.1$ & $53.1 \pm 4.1$ \\
\hline G11(3) & $39.1 \pm 3.6$ & $81.6 \pm 2.9$ & $50.1 \pm 4.0$ \\
\hline G7(2) & $25.8 \pm 3.1$ & $84.0 \pm 3.5$ & $60.1 \pm 6.9$ \\
\hline MI23-1 & $31.5 \pm 2.1$ & $66.7 \pm 1.4$ & $33.3 \pm 4.4$ \\
\hline MB26-1 & $27.3 \pm 1.5$ & $97.4 \pm 2.1$ & $58.3 \pm 7.6$ \\
\hline
\end{tabular}

${ }^{a}$ HX2 was cultured in liquid PDA medium and grown on a shaker. Cells were pelleted and washed twice with sterile distilled water and then suspended in sterile buffered saline to get an $\mathrm{OD}_{600}$ of 0.6 $\left(2 \times 10^{8} \mathrm{CFU} / \mathrm{ml}\right)$. Supernatant was retained. Suspension of the agrobacterial strain $\left(2 \times 10^{8} \mathrm{CFU} / \mathrm{ml}\right)$ was mixed with two volumes of the supernatant, sterile buffered saline, or cell suspension of HX2. Crown gall tumor inhibition activity was calculated. Crown gall tumor inhibition $(\%)=[(C-T) / C] \times$ 100 , where $C$ is average weight of crown gall tumor of control group, and $T$ is average weight of crown gall tumor of treated group.

b Standard error. 
treated and nontreated with $\mathrm{HX} 2$ were 32.5 and $96.3 \%$, respectively, and the crown gall tumor inhibition was $77.9 \%$. In the last year, incidences of crown gall on plants treated and nontreated with $\mathrm{HX} 2$ were 28.8 and $90 \%$, respectively, and the crown gall tumor inhibition was $81.0 \%$. Weight of tumors of plants treated with HX2 was greatly reduced, and disease incidence in grape plants treated with $\mathrm{HX} 2$ decreased from 93.5 to $30.8 \%$.

HX2 colonization in grapevine roots. The HX2 cell line transformed with pSMC2 plasmid containing $g f p$, and des- ignated as $g f p-\mathrm{HX} 2$, showed the same characteristics of growth, motility, and production of antimicrobial substances as the wild-type cell lines. Population sizes of the $g f p-\mathrm{HX} 2$ were determined up to 120 days after root inoculation. The colonization dynamics of $g f p-\mathrm{HX} 2$ on grapevines were shown in Figure 4. Randomly selected $g f p$ HX2 colonies showed similar antagonistic activity against $A$. vitis K308. The $16 \mathrm{~S}$ rDNA amplified from these colonies was the same as that of HX2. No fluorescent colony was detected when plants were sampled on the 120th day after inoculation.

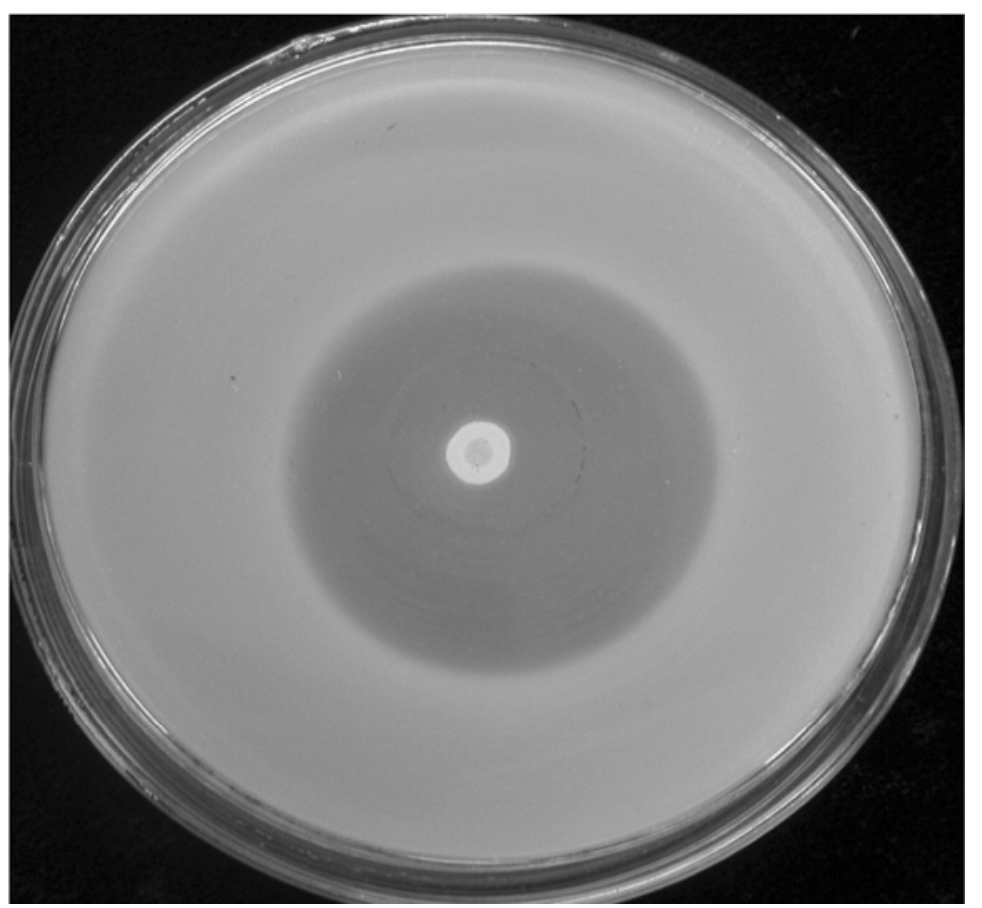

Fig. 1. Inhibitory effect of Rahnella aquatilis HX2 against Agrobacterium vitis K308. Inhibition zone production by $\mathrm{HX} 2$ on potato dextrose agar medium plate (incubation at $28^{\circ} \mathrm{C}$ for $48 \mathrm{~h}$ ).
Effects of HX2 on the root microflora population of grapevine. No significant difference was found in the mean population sizes of root microflora between control plants and plants treated with $\mathrm{HX} 2$ when we sampled the plants on the 15 th, 30th, 60th, and 90th day after inoculation. A significant impact of HX2 on the total cell density of bacteria was observed on the first sampling time $(P<0.05)$. The population of root bacteria of plants treated with HX2 and control plants were $1.3 \times$ $10^{5} \mathrm{CFU} / \mathrm{g}$ and $2.3 \times 10^{4} \mathrm{CFU} / \mathrm{g}$, respectively.

\section{DISCUSSION}

The biological control assays showed that the strain HX2 efficiently controlled the pathogenic agrobacterial strain $A$. vitis K308 under field conditions. The antibiotic substances produced by HX2 may play an important role. Treatment with the antagonistic bacterium not only decreased the proportion of plants with visible symptoms of crown gall but also reduced the disease severity of affected plants.

Gavini et al. (17) used the name the Group $\mathrm{H}_{2}$ for phenotypically similar strains during a taxonomic study of the genus of Enterobacter. Izard et al. (21) named the organisms Rahnella aquatilis. Biochemically, Rahnella sp. is closely related to Enterobacter agglomeransPantoea agglomerans complex. $R$. aquatilis can grow at $4^{\circ} \mathrm{C}$ and $10^{\circ} \mathrm{C}$ and does not produce yellow pigment. It is negative for lysine and ornithine decarboxylase reactions. Therefore, it can be differentiated from other members of the former complex (26). In this study, the biochemical results of HX2 were consistent with the characterizations of $R$. aquatilis. HX2 16S rDNA sequence was 99\% similar to that of the genus Rahnella.
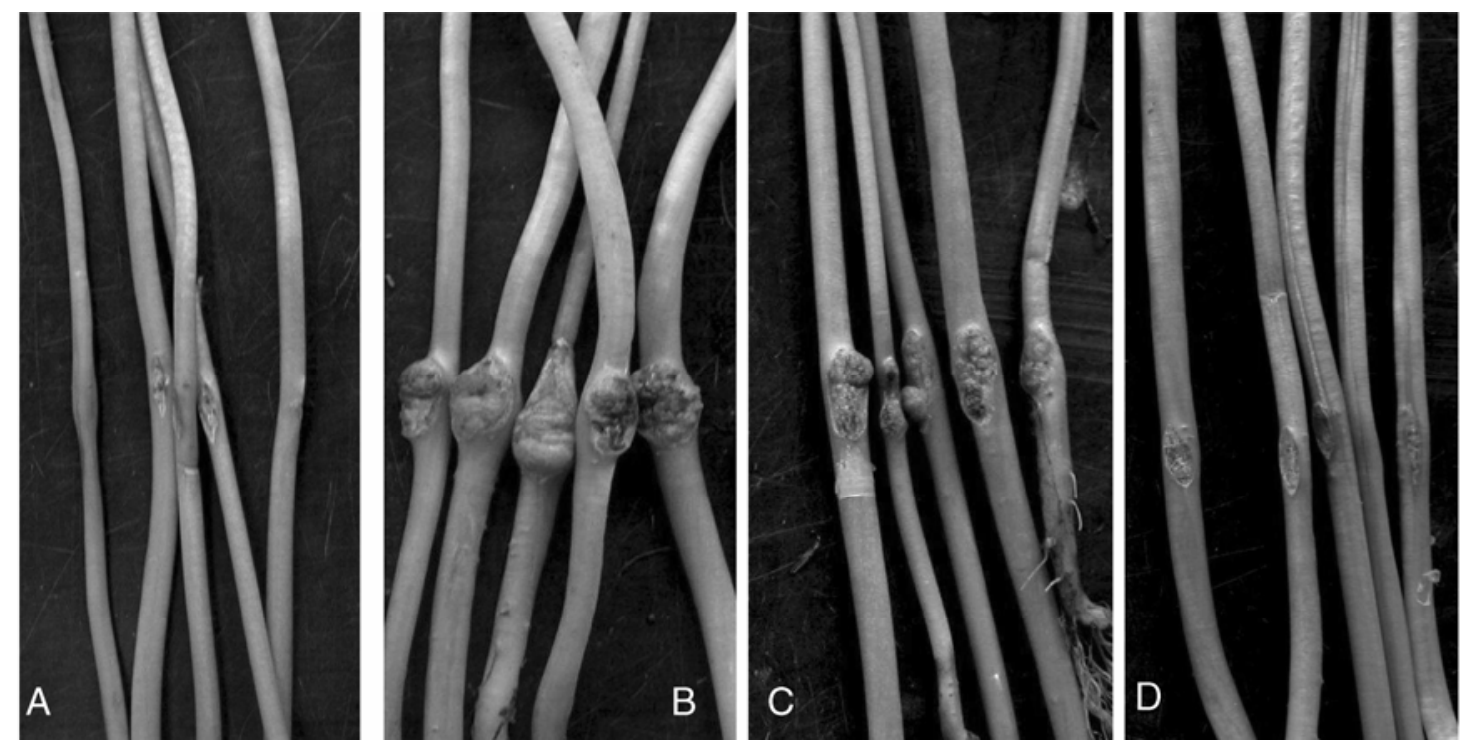

Fig. 2. Inhibition by Rahnella aquatilis $\mathrm{HX} 2$ of sunflower tumor development by Agrobacterium vitis K308. A, inoculated with HX2 supernatant and K308 mixture (2:1); B, inoculated with K308 only; C, inoculated with HX2 cell suspension and K308 mixture (2:1); D, sterile buffered saline inoculation as negative control. 
The genus of Rahnella is widely distributed in water and soil $(3,5,19)$, as well as in foods and seeds $(8,30)$. Some strains of $R$. aquatilis were rhizosphere-associated bacteria and nitrogen fixers (3) and have the ability to solubilize mineral phosphate (25). It has been reported that Rahnella aquatilis JC577 has in vitro antagonistic activity against $A$. vitis, whereas this strain showed no biocontrol effect on grapevine crown gall disease (2). Furthermore, two strains of Rahnella can effectively suppress bacterial spot of tomato caused by Xanthomonas campestris pv. vesicatoria (14).

Some strains of Enterobacter, which are closely related to Rahnella, have been described as potential biological control agents for different fungal phytopathogens (29,32). Strain JC1270 of Enterobacter agglomerans, which can produce a complex of chitinolytic enzymes and an antibiotic, has been reported as an antagonist of many fungal phytopathogens $(11,12)$. The ability to produce an antibiotic-like substance was considered to be an important factor for inhibition of Phytophthora cactorum by Enterobacter aerogenes strain B8 (43). Moreover, it is known that $\mathrm{K} 84$ is able to produce a highly specific antibiotic, agrocin 84, which is effective against many pathogenic Agrobacterium strains (22).

The possible roles of the different antibiotics produced by strain K84 during pathogen infection of plant cells had been investigated before $(13,37,41)$. In a previous study, we observed that when HX2 strain was cultured in media containing dextrose, the amount of antibiotic substances was higher than in media with other carbon sources (data not shown). In this paper, we have shown that HX2 inhib- ited the growth of pathogenic agrobacterial strains in vitro. The inhibition effect of HX2 is likely due to antibiotic substances that prevented tumor formation, since the effect of the culture supernatant on crown gall was stronger than that of the cell suspension.

Production of siderophores and accumulation of toxic metabolites (such as $\mathrm{HCN}$ ) have been considered important factors in biological control $(34,49)$. Strain HX2 did not show any evidence that it could produce siderophore or $\mathrm{HCN}$.

Our data demonstrated that HX2 had colonized and survived in the rhizosphere of grapevine for only 3 months, which indicated that the colonization ability may play a minor or dispensable role in the mechanism of biological control of crown gall disease by HX2. Rhizosphere colonization ability was considered as a possible mechanism of antifungal activity in Enterobacter agglomerans (18). K84 could control the crown gall caused by agrocin 84 resistant pathogens, suggesting that other traits of the strain K84 are involved in its biological control mechanisms (33). Farrand and Wang (16) considered that colonization played a role in crown gall biological control by the strain K84 but was not the most important parameter. The strain of K84 could inhibit the formation of tumors by different mechanisms including the physical block-

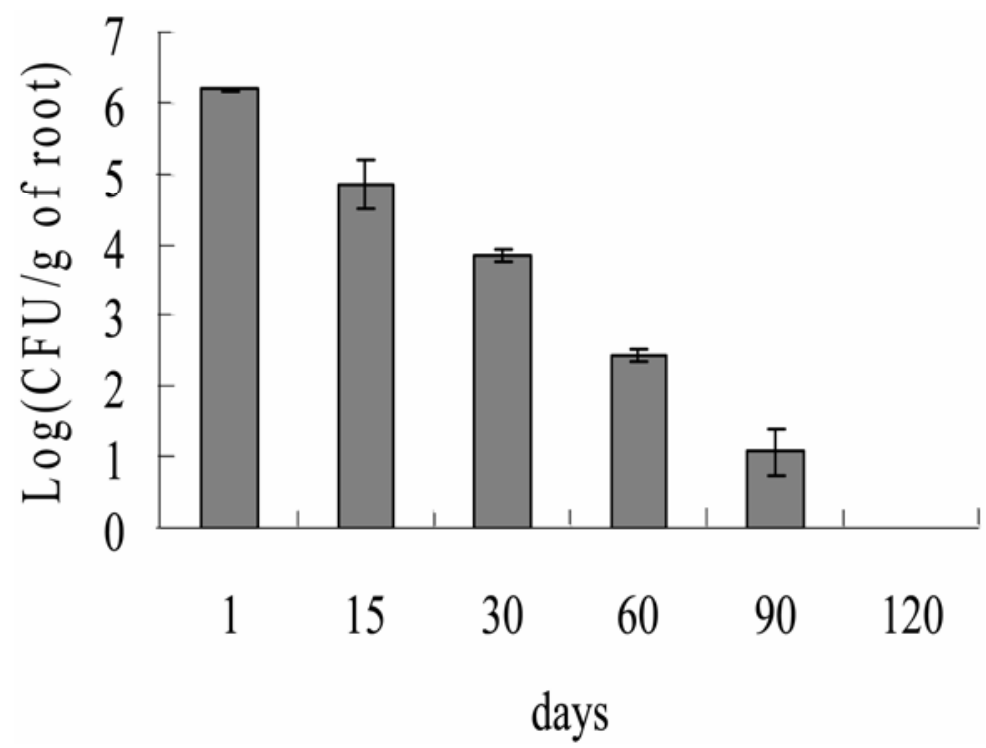

Fig. 4. Population size of Rahnella aquatilis $\mathrm{HX} 2$ on grapevine roots 120 days after inoculation. yaxis: population size (CFU per gram [fresh weight] of root) of HX2; X-axis: numbers represent days after inoculation.
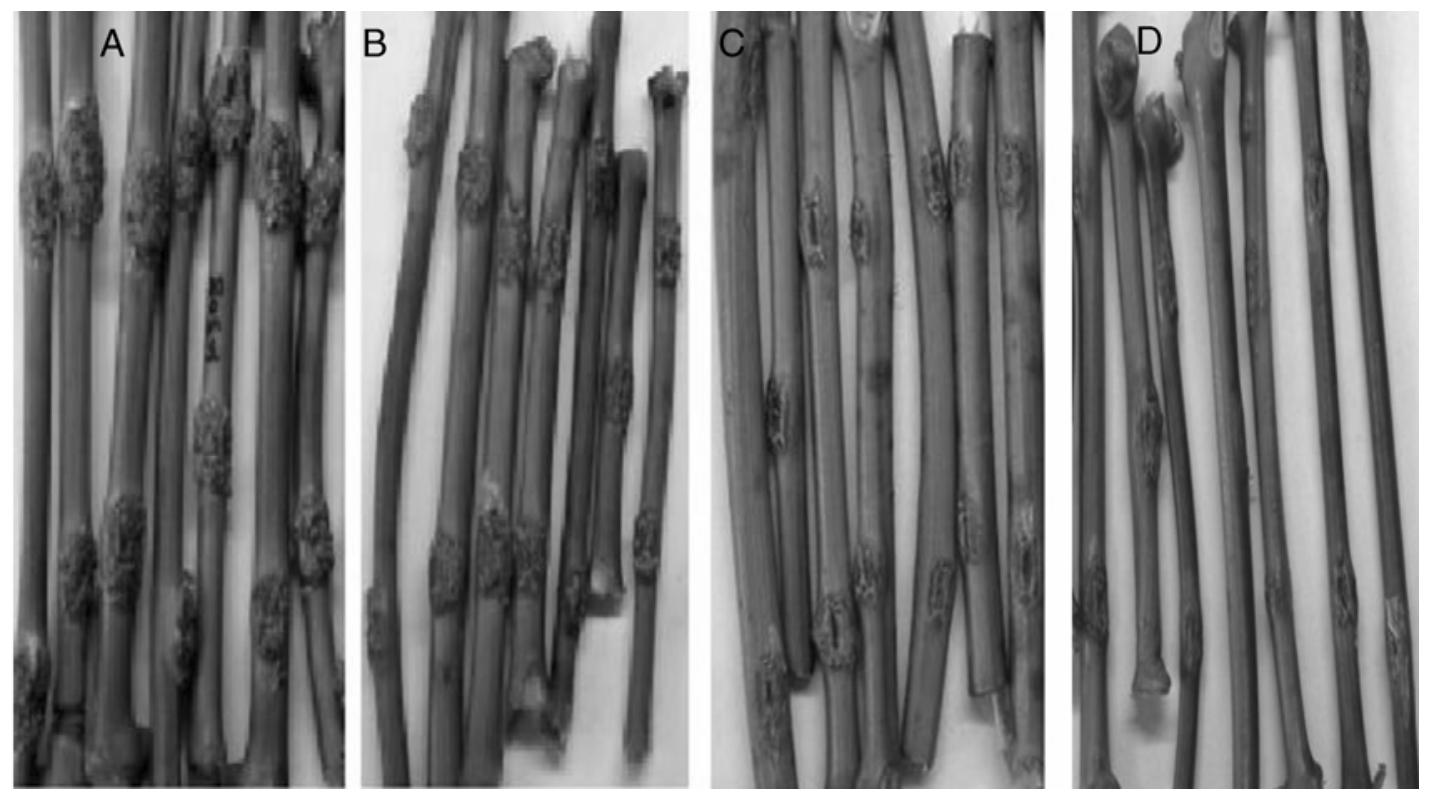

Fig. 3. Inhibition by Rahnella aquatilis $\mathrm{HX} 2$ of Agrobacterium vitis K308-induced grape tumor development. A, inoculated with K308 only; B, inoculated with HX2 cell suspension and K308 mixture (2:1); C, inoculated with HX2 supernatant and K308 mixture (2:1); D, inoculated with sterile buffered saline as the negative control. 
ing of the infection sites (28) and/or antibiosis $(13,35)$ or a combination of these or other mechanisms at the primary sites of infection.

We have demonstrated that the supernatant and cell suspension of HX2 had no detrimental effect on the total cell density of three microfloral components of rhizosphere: bacteria, fungi, and actinomyces. However, it is not known if the supernatant or cell suspension will affect other beneficial microorganisms under other conditions.

\section{ACKNOWLEDGMENTS}

The authors thank Mr. Q. Wei and Mr. B. Hu for their technical assistance.

\section{LITERATURE CITED}

1. Ausubel, F., Brent, R., Kingston, R. E., Moore, D. D., Seidman, J. G., Smith, J. A., and Struhl, K., eds. 1997. Short Protocols in Molecular Biology, 3rd ed. John Wiley \& Sons, New York.

2. Bell, C. R., Dickie, G. A., and Chan, J. W. Y. F. 1995. Variable response of bacteria isolated from grapevine xylem to control grape crown gall disease in planta. Am. J. Enol. Vitic. 46:499-508.

3. Berge, O., Heulin, T., Achouak, W., Richard, C., Bally, R., and Balandreau, J. 1991. Rahnella aquatilis, a nitrogen-fixing enteric bacterium associated with the rhizosphere of wheat and maize. Can. J. Microbiol. 37:195-203.

4. Bloemberg, G. V., O'Toole, G. A., Lugtenberg, B. J., and Kolter, R. 1997. Green fluorescent protein as a marker for Pseudomonas spp. Appl. Environ. Microbiol. 63:4543-4551.

5. Brenner, D. J., Muller, H. E., Steigerwalt, A. G., Whitney, A. M., O'Hara, C. M., and Kampfer, P. 1998. Two new Rahnella genomospecies that cannot be phenotypically differentiated from Rahnella aquatilis. Int. J. Syst. Bacteriol. 48:141-149.

6. Burr, T. J., and Katz, B. H. 1983. Isolation of Agrobacterium tumefaciens biovar 3 from grapevine galls and vineyard soil. Phytopathology 73:163-165.

7. Burr, T. J., and Reid, C. L. 1994. Biological control of grape crown gall with nontumorigenic Agrobacterium vitis strain F2/5. Am. J. Enol. Vitic. 45:213-219.

8. Cankar, K., Kraigher, H., Ravnikar, M., and Rupnik, M. 2005. Bacterial endophytes from seeds of Norway spruce (Picea abies L. Karst). FEMS Microbiol. Lett. 244:341-345.

9. Castric, K. F., and Castric, P. A. 1983. Method for rapid detection of cyanogenic bacteria. Appl. Environ. Microbiol. 45:701-702.

10. Chen, X. Y., and Xiang, W. N. 1986. A strain of Agrobacterium radiobacter inhibits growth and gall formation by biotype III strains of $A$. tumefaciens from grapevine. Acta Microbiol. Sinica 26:193-199.

11. Chernin, L., Brandis, A., Ismailov, Z., and Chet, I. 1996. Pyrrolnitrin production by an Enterobacter agglomerans strain with a broad spectrum of antagonistic activity towards fungal and bacterial phytopathogens. Curr. Microbiol. 32:208-212.

12. Chernin, L., Ismailov, Z., Haran, S., and Chet, I. 1995. Chitinolytic Enterobacter agglomerans antagonistic to fungal plant pathogens. Appl. Environ. Microbiol. 61:1720-1726.

13. Donner, S. C., Jones, D. A., McClure, N. C., Rosewarne, G. M., Tate, M. E., Kerr, A., Fajardo, N. N., and Clare, B. G. 1993. Agrocin 434 , a new plasmid-encoded agrocin from the biocontrol Agrobacterium strains $\mathrm{K} 84$ and K1026, which inhibits biovar 2 agrobacteria. Physiol. Mol. Plant Pathol. 42:185-194.
14. El-Hendawy, H. H., Osman, M. E., and Sorour, N. M. 2005. Biological control of bacterial spot of tomato caused by Xanthomonas campestris pv. vesicatoria by Rahnella aquatilis. Microbiol. Res.160:343-352.

15. Fang, Z. D. 1998. Research technology for plant pathology. China Agricultural Press, Beijing.

16. Farrand, S. K., and Wang, C. 1992. Do we really understand crown gall control by Arobacterium radiobacter strain K84? Pages 287293 in: Biological Control of Plant Diseases. E. S. Tjamos et al., eds. Plenum Press, New York.

17. Gavini, F., Ferragut, C., Lefebvre, B., and Leclerc, H. 1976. Etude taxonomique d'enterobacteries appartenant ou apparentees au genre Enterobacter. Ann. Microbiol. (Institut Pasteur) 127B:317-335.

18. Hebbar, K. P., Davey, A. G., Merrin, J., and Dart, P. J. 1992. Rhizobacteria of maize antagonistic to Fusarium moniliforme, a soilborne fungal pathogen: Colonization of rhizosphere and roots. Soil Biol. Biochem. 24:989-997.

19. Heulin, T., Berge, O., Mavingui, P., Gouzou, L., Hebbar, K. P., and Balandreau, J. 1994. Bacillus polymyxa and Rahnella aquatilis the dominant $\mathrm{N}_{2}$-fixing bacteria associated with wheat rhizosphere in French soils. Eur. J. Soil Biol. 30:35-42.

20. Iimura, K., and Hosono, A. 1996. Biochemical characteristics of Enterobacter agglomerans and related strains found in buckwheat seeds. Int. J. Food Microbiol. 30:243-253.

21. Izard, D. M., Gavini, F., Trinel, P. A., and Leclerc, H. 1979. Rahnella aquatilis, nouveau membre de la famille des Enterobacteriaceae. Ann. Microbiol. (Institut Pasteur) 130A:167177.

22. Kerr, A. 1980. Biological control of crown gall through production of agrocin 84 . Plant Dis. 64:28-30.

23. Kerr, A., and Panagopoulos, C. G. 1977. Biotypes of Agrobacterium radiobacter var. tumefaciens and their biological control. J. Phytopathol. 90:172-179.

24. Khmel, I. A., Sorokina, T. A., Lemanova, N. B., Lipasova, V. A., Metlitski, O. Z., Burdeinaya, T. V., and Chernin, L. S. 1998. Biological control of crown gall in grapevine and raspberry by two Pseudomonas spp. with a wide spectrum of antagonistic activity. Biocontrol Sci. Technol. 8:45-57.

25. Kim, K. Y., Jordan, D., and Krishnan, H. B. 1998. Expression of genes from Rahnella aquatilis that are necessary for mineral phosphate solubilization in Escherichia coli. FEMS Microbiol. Lett. 159:121-127.

26. Krieg, N. R., and Holt, J. G. 1984. Bergey's Manual of Systematic Bacteriology. Williams \&Wilkins, Baltimore, MD. p. 513.

27. LaPointe, G., Nautiyal, C. S., Chilton, W. S., Farrand, S. K., and Dion, P. 1992. Spontaneous mutation conferring the ability to catabolize mannopine in Agrobacterium tumefaciens. J Bacteriol. 174:2631-2639.

28. Lippincott, B. B., and Lippincott, J. A. 1969. Bacterial attachment to a specific wound site as an essential stage in tumor initiation by Agrobacterium tumefaciens. J. Bacteriol. 97:620-628.

29. Nelson, E. B. 1988. Biological control of Pythium seed rot and preemergence dampingoff of cotton with Enterobacter cloacae and Erwinia herbicola applied as seed treatments. Plant Dis. 72:140-142.

30. Olsson, C., Ahrne, S., Pettersson, B., and Molin, G. 2004. DNA based classification of food associated Enterobacteriaceae previously identified by Biolog GN Microplates. Syst. Appl. Microbiol. 27:219-228.

31. Ophel, K., and Kerr, A. 1990. Agrobacterium vitis sp. nov. for strains of Agrobacterium bio- var 3 from grapevines. Int. J. Syst. Bacteriol. 40:236-241

32. Park, J. H., and Kim, H. K. 1989. Biological control of Phytophthora crown and root rot of greenhouse pepper with Trichoderma harzianum and Enterobacter agglomerans by improved method of application. Korean J. Plant Pathol. 5:1-12.

33. Penyalver, R., and Lopez, M. 1999. Cocolonization of the rhizosphere by pathogenic Agrobacterium strains and nonpathogenic strains K84 and K1026, used for crown gall biocontrol. Appl. Environ. Microbiol. 65:1936-1940.

34. Penyalver, R., Oger, P., Lopez, M. M., and Forrand, S. K. 2001. Iron-binding compounds from Agrobacterium spp.: Biological control strain Agrobacterium rhizogenes $\mathrm{K} 84$ produces a hydroxamate siderophore. Appl. Environ. Microbiol. 67:654-664

35. Penyalver, R., Vicedo, B., Salcedo, C. I., and Lopez, M. M. 1994. Agrobacterium radiobacter strains K84, K1026 and K84 Agr-produce an antibiotic-like substance, active in vitro against $A$. tumefaciens and phytopathogenic Erwinia and Pseudomonas. Biocontrol Sci. Technol. 4:259-267.

36. Provence, D. L., and Curtiss, R., III. 1994 Gene transfer in gram-negative bacteria. Pages 317-347 in: P. Gerhardt, R. G. E. Murray, W. A. Wood, and N. R. Krieg, eds. Methods for General and Molecular Bacteriology. American Society for Microbiology, Washington, DC.

37. Roberts, W. P., Tate, M. E., and Kerr, A. 1977. Agrocin 84 is a $6-N$-phosphoramidate of an adenine nucleotide analogue. Nature 265:379381.

38. Sambrook, J., Fritsch, E. F., and Maniatis, T. 1989. Molecular Cloning: A Laboratory Manual, 2nd ed. Cold Spring Harbor Laboratory, Cold Spring Harbor, NY.

39. Schwyn, B., and Neilands, J. B. 1987. Universal chemical assay for the detection and determination of siderophores. Anal. Biochem. 160:47-56.

40. Stonier, T. 1960. Agrobacterium tumefaciens Conn II. Production of an antibiotic substance. J. Bacteriol. 79:889-898.

41. Tate, M. E., Murphy, P. J., Roberts, W. P., and Kerr, A. 1979. Adenine N6-substituent of agrocin 84 determines its bacteriocin-like specificity. Nature 280:697-699.

42. Thomson, J. A. 1986. The potential for biological control of crown gall disease on grapevines. Trends Biotechnol. 4:219-224.

43. Utkhede, R. S., and Gaunce, A. P. 1983. Inhibition of Phytophthora cactorum by a bacterial antagonist. Can. J. Bot. 61:3343-3348.

44. Utkhede, R. S., and Smith, E. M. 1993. Evaluation of biological and chemical treatments for control of crown gall on young apple trees in the Kootenay valley of British Columbia. J. Phytopathol. 137:265-271.

45. Van der Bij, A. J., de Weger, L. A., Tucker, W. T., and Lugtenberg, B. J. J. 1996. Plasmid stability in Pseudomonas fluorescens in the rhizosphere. Appl. Environ. Microbiol. 62: 1076-1080

46. Van Larebeke, N., Genetello, C. H., Hernalsteens, J. P., De Picker, A., Zaenen, I., Messens, E., Van Montagu, M., and Schell, J. 1977. Transfer of Ti plasmids between Agrobacterium strains by mobilization with the conjugative plasmid RP4. Mol. Gen. Genet. 152:119124.

47. Vicedo, B., Penalver, R., Asins, M. J., and Lopez, M. M. 1993. Biological control of Agrobacterium tumefaciens, colonization, and pAgK84 transfer with Agrobacterium radiobacter K84 and the Tra- mutant strain K1026. Appl. Environ. Microbiol. 59:309-315.

48. Webster, J., Santos, M., and dos Thomson, J. A. 1986. Agrocin-producing Agrobacterium 
tumefaciens strain active against grapevine isolates. Appl. Environ. Microbiol. 52:217-219.

49. Wei, H. L., Wang, Y., Zhang, L. Q., and Tang, W. H. 2004. Identification and characterization of biocontrol bacterial strain 2P24 and CPF10. Acta Phytopathol. Sinica 34:80-85.

50. Whatley, M. H., Margot, J. B., Schell, J.,
Lippincott, B. B., and Lippincott, J. A. 1978. Plasmid and chromosomal determination of Agrobacterium adherence specificity. J. Gen. Microbiol. 107:395-398.

51. Xie, X. M., You, J. F., Chen, P. M., and Guo, J. M. 1993. On a strain MI 15 of Agrobacterium radiobacter for the biological control of grapevine crown gall. Acta Phytopathol. Sinica 23:137-141

52. Zhang, C. M., Lu, S. H., Wei, C. M., and Zhao, J. H. 1991. Bacterium strain 1-1-4 Pseudomonas fluorescent for biocontrol of peach crown gall disease. Acta Agric. Shanghai 7:65-69. 